\title{
Validation of Korean-Language Version of Chronic Otitis Media Questionnaire-12 to Reflect the Disease Activity of Chronic Otitis Media
}

\author{
Tae Hoon Kong ${ }^{1}$ D, Ye Ji Shin ${ }^{2}$, Chul Hyo Kuㄹ, Sang Man Park ${ }^{1}$, Yoon Ah Park ${ }^{1}$, and Sang Yoo Park ${ }^{1}$ D \\ ${ }^{1}$ Departments of Otorhinolaryngology-Head and Neck Surgery, ${ }^{2}$ Medicine, Yonsei University Wonju College of Medicine, Wonju, Korea
}
만성 중이염의 질병 활성도를 반영하는 한국어판 만성중이염설문-12(COMQ-12)의 타당도 및 신뢰도 검증

공태훈 ${ }^{1} \cdot$ 신예지 $^{2} \cdot$ 구철효 $^{1} \cdot$ 박상만 $^{1} \cdot$ 박윤아 $^{1} \cdot$ 박상유 $^{1}$

연세대학교 원주의과대학 이비인후과학교실, ${ }^{1}$ 연세대학교 원주의과대학 의학과학교실 ${ }^{2}$

\author{
Received July 3,2018 \\ Revised October 18, 2018 \\ Accepted October 29, 2018 \\ Address for correspondence \\ Sang Yoo Park, MD, PhD \\ Department of Otorhinolaryngology- \\ Head and Neck Surgery, \\ Yonsei University Wonju \\ College of Medicine, \\ 20 Ilsan-ro, Wonju 26426, Korea \\ Tel $+82-33-741-0642$ \\ Fax $+82-33-732-8287$ \\ E-mailsangyoo3@yonsei.ac.kr
}

\begin{abstract}
Background and Objectives The Chronic Otitis Media Questionnaire-12 (COMQ-12) was developed in the United Kingdom to assess disease specific Health-Related Quality of Life (HRQoL) of chronic otitis media (COM) patients. We assessed the validity of Korean version of COMQ-12 (K-COMQ-12) and its correlation with the disease activity of COM classified according to the type of surgery.

Materials and Method We translated the original COMQ-12 into Korean and also performed a back-translation of the translated text into English. Enrolled were $106 \mathrm{COM}$ patients and 106 healthy subjects. Cronbach alpha was used to evaluate internal consistency, and factor analysis was performed to prove reliability. We compared K-COMQ-12 scores between normal subjects and COM patients to assess validity. The scores were also compared by dividing groups according to disease activity of COM.

Results Cronbach's alpha showed good internal consistency (0.939). There was a significant difference in K-COMQ-12 scores between healthy subjects $(1.99 \pm 4.34)$ and COM patients $(22.69 \pm 12.41)$. Also, scores go higher as the disease activity of COM increased. A cut-off score of 6 of K-COMQ-12 sets 0.915 of sensitivity and 0.934 of specificity.

Conclusion The K-COMQ-12 is a reliable and valid tool to assess HRQoL in patients with COM. The K-COMQ-12 could be also used as an objective tool that reflects the disease activity of COM. Korean J Otorhinolaryngol-Head Neck Surg 2019;62(6):323-31
\end{abstract}

Key Words Chronic otitits media · Chronic Otitis Media Questionnaire 12 . Patient-reported outcome · Questionnaire · Quality of life.

\section{Introduction}

Chronic otitis media (COM) is a common disease, its incidence has been reported as $2 \%$ of the worldwide population. ${ }^{1)}$ Following the data from the Korean National Health and Nu-

This is an Open Access article distributed under the terms of the Creative Commons Attribution Non-Commercial License (https://creativecommons.org/licenses/by-nc/4.0) which permits unrestricted non-commercial use, distribution, and reproduction in any medium, provided the original work is properly cited. trition Examination Survey 2010-2012, Korean prevalence of $\mathrm{COM}$ was $3.8 \%$, which is slightly higher than the average of worldwide. ${ }^{2)}$ There has been many treatment ways including medication, frequent dressing and surgery to treat COM, but surgery still remains a key treatment of COM and COM related complications. ${ }^{3,4)}$

Decisions about whether or not to perform ear surgery of COM are made by an otolaryngologist based on various 
clinical results. ${ }^{5)}$ Patients with COM were performed many clinical evaluation such as physical examination, pure tone audiometry (PTA), temporal bone computed tomography (TBCT) before surgery. However, many of otolaryngologists are likely to overlook how much suffering a patient has due to $\mathrm{COM}$. Also, as there were insufficient tools to quantify the patient's discomfort due to symptoms of COM, the severity of the patient's symptoms and the impact on the quality of life were dependent only on the patient's each level of expression. ${ }^{6}$ )

The Health-Related Quality of Life (HRQoL) which means the degree of patient's satisfaction of their life influenced by disease, and it concerns patient's total health status. ${ }^{7)}$ In the assessment of healthcare, patient-based measuring instruments regarding the quality of life and perceived handicap have become increasingly important. ${ }^{8}$ To develop measurement of disease-specific HRQoL of COM, Phillips, et al. ${ }^{8)}$ developed the Chronic Otitis Media Questionnaire-12 (COMQ12) using selected questions from following tools; chronic ear survey (CES), Chronic Otitis Media Outcome Test-15 (COMOT-15), COM-5. ${ }^{1,8-10)}$

The original version of COMQ-12 was made in English, and needed to develop other language version to use the COMQ12 widely so that many of COM patients would benefit. Dutch, Russian, Portuguese, Servian, as well as Indian Kannada version are already validated, but no other language version is used yet. $^{11-16)}$

In our study, we assessed the validity of Korean version of COMQ-12 (K-COMQ-12) and correlation with the disease activity of COM classified according to physical examination. Also we found meaningful cut-off values between COM patients and normal subjects using K-COMQ-12.

\section{Materials and Method}

\section{The original author's agreement}

The corresponding author sent e-mail to Dr. John Phillip, the original author of COMQ-12, and obtained permission and received the original version of COMQ-12.

\section{The K-COMQ-I2}

The original English version of COMQ-12 consists of 12 questions. Each item is scored from 0 to 5, the higher number the more discomfort it means. The original COMQ-12 was translated from English to Korean by bilingual otolaryngologist in English and Korean. Next, the translation was checked by a person who majored in Korean literature. Then the na- ive Korean version was translated back to English. Both the original and retranslated English version of the COMQ-12 were compared by a person who majored in English literature and suggested minor changes (Appendix 1).

\section{Subjects}

Power analysis were performed to estimate the number of subjects (effect size 0.28, a-risk 0.05). In total, 212 individuals were enrolled in this study. One hundred and six patients who visited Yonsei University Wonju Severance Christian Hospital and diagnosed COM and planned surgery were enrolled in the study. To compare with control group, 106 healthy volunteers who have not experienced COM were asked randomly from Yonsei University Wonju Severance Christian Hospital.

All subjects participated in informed voluntary consent, and were independently answered each question of K-COMQ-12. In case of COM patients, they answered to K-COMQ-12 before they took surgery. There was no reported difficulties answering each question, and participants received no help in answering questions. Patients who could not read and understand the Korean-language were not enrolled in this study. Demographic informations of subjects such as patient's sex, age and body mass index (BMI) were collected. Informations of medical history, including hypertension, diabetes mellitus, lung or heart disease, cerebrovascular accident, chronic kidney disease, liver disease and frequency of noise exposure were also collected.

The Institutional Review Board of Yonsei University Wonju Severance Christian Hospital approved this study (CR316063).

\section{Statistical analysis}

Statistical analysis was conducted using the Statistical Package for Social Sciences Software (SPSS 22.0 IBM Corp., Armonk, NY, USA). Cronbach's alpha and item-total correlation were measured to evaluate internal consistency. We used Kaiser-Meyer-Olkin (KMO) test to measure sampling adequacy. KMO value is considered 'good' if it is greater than 0.70, and 'excellent' if it is greater than 0.90. Generally, it is known that factor analysis is appropriate if the KMO value is greater than 0.7 . We also performed factor analysis, and the number of factors was determined using the eigenvalue and scree plot curve. Varimax rotation was used to simplify the interpretation of data. The independent t-test and one-way analysis of variance with Bonferroni method for continuous variables, chi-square or Fisher's exact test for cate- 
gorical variables were performed to construct validity. To facilitate the clinical interpretation of K-COMQ-12 scores, a threshold score for distinguishing normal from patients of $\mathrm{COM}$ was derived from the receiver operating characteristic (ROC) curve. We assessed significant differences when the $p$-value was less than $0.05(p<0.05)$.

\section{Results}

\section{Reliability}

For the K-COMQ-12, Cronbach's alpha was 0.939, suggesting good internal consistency. We also assessed item-to-

Table 1. Item-total correlation coefficients for each item on KCOMQ-12

\begin{tabular}{cc}
\hline Item no. & Item-total correlation \\
\hline 1 & 0.731 \\
2 & 0.636 \\
3 & 0.801 \\
4 & 0.768 \\
5 & 0.822 \\
6 & 0.652 \\
7 & 0.724 \\
8 & 0.740 \\
9 & 0.548 \\
10 & 0.756 \\
11 & 0.724 \\
12 & 0.810
\end{tabular}

K-COMQ-12: Korean version of Chronic Otitis Media Questionnaire-12

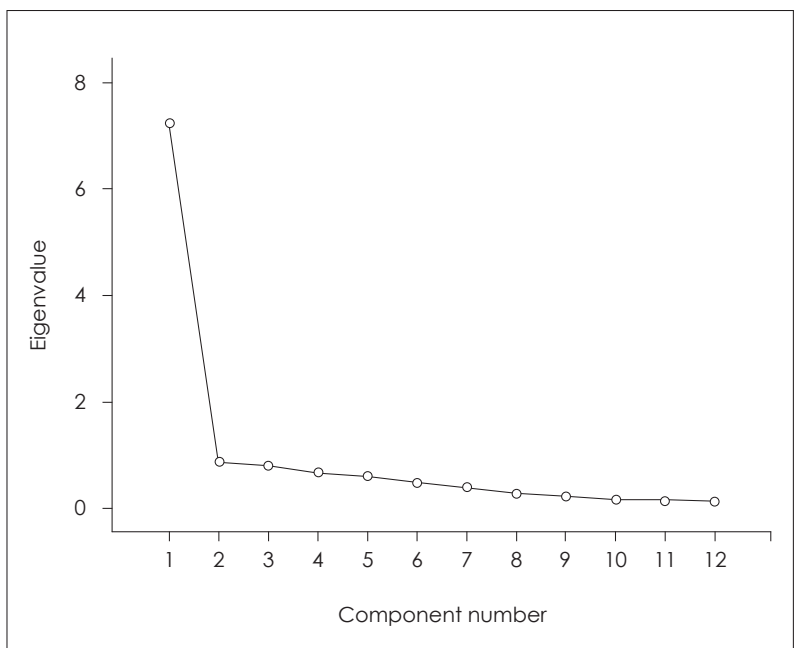

Fig. 1. Scree plot. The number of factors was determined following eigenvalue or the component number, which represents the degree of scree plot. In our study, the scree plot shows that two of those factors explain most of the variability because the line starts to straighten after factor 2 . The remaining factors explain a very small proportion of the variability. tal correlation coefficients. It ranged from 0.548 to 0.822 that indicates all individual items correlated well with the total score (Table 1).

\section{Factor analysis}

As the KMO value was 0.884 , factor analysis is appropriate for our data. Factor analysis is generally used to group items of questionnaire with similar features. We determined the 2 factors were extracted using eigenvalues and a scree plot curve (Fig. 1). They explained $60.26 \%$ and $7.33 \%$ of all items of K-COMQ-12. The factor 1 includes 9 items (item 3, $4,5,6,7,8,10,11,12$ ), and the factor 2 includes 3 items (item 1, 2, 9) (Table 2). However, we could not find appropriate titles covering the items that make up each factor.

The item-communality values, which refers to the amount

Table 2. Two factors of the K-COMQ-12 by rotated component matrix

\begin{tabular}{ccc}
\hline Item no. & Factor 1 & Factor 2 \\
\hline 1 & 0.365 & 0.809 \\
2 & 0.211 & 0.861 \\
3 & 0.831 & 0.296 \\
4 & 0.826 & 0.256 \\
5 & 0.624 & 0.599 \\
6 & 0.592 & 0.389 \\
7 & 0.741 & 0.307 \\
8 & 0.762 & 0.298 \\
9 & 0.304 & 0.599 \\
10 & 0.630 & 0.497 \\
11 & 0.559 & 0.546 \\
12 & 0.781 & 0.373 \\
\hline
\end{tabular}

K-COMQ-12: Korean version of Chronic Otitis Media Questionnaire-12

Table 3. Communality values for each item on K-COMQ-12

\begin{tabular}{cc}
\hline Item no. & Communality \\
\hline 1 & 0.787 \\
3 & 0.785 \\
4 & 0.777 \\
5 & 0.748 \\
6 & 0.748 \\
7 & 0.501 \\
8 & 0.642 \\
9 & 0.670 \\
10 & 0.451 \\
11 & 0.642 \\
12 & 0.610 \\
\hline
\end{tabular}

K-COMQ-12: Korean version of Chronic Otitis Media Questionnaire-12 
of variance of an item as predicted by the loading factor, ranged from 0.451 to 0.787 (Table 3). Generally, it is considered that each item loads well on factor when the value of communality is greater than 0.45 .

\section{Construct validity}

We assessed the construct validity of K-COMQ-12 by comparing scores from COM patients to those of the control group. Among total 212 subjects which consist of 106 COM group and 106 normal group, clinical baseline characteristics of each group are shown in Table 4. There were no significant differences in many factors including subject's age, sex, BMI and their medical histories. $34.9 \%$ of COM patients were performed previous ear surgery, $14.2 \%$ of COM patients had experience of noise exposure, and $11.3 \%$ had or had been wearing hearing aids in the past. They were statistically significant when comparing normal group (Table 4).

The control group showed 1.99 of mean K-COMQ-12 score [4.34 of standard deviation (SD)] whereas the COM group showed 22.69 (12.41 of SD), and they were statistically significant (Table 5).

\section{Disease activity of COM and K-COMQ-12 scores}

We classified the severity of COM according to the surgery which the patient decided to undergo. Typically, long-lasted infection with poor Eustachian tube function induces relatively severe COM, and usually requires mastoidectomy, however, tympanoplasty only is often sufficient for COM with relatively intact eustachian tube function and relatively shortlasting COM. ${ }^{17)}$ Following the type of surgery, $106 \mathrm{COM}$ subjects were divided into two groups; the 'Tympanoplasty only' group and the 'Mastoidectomy' group. The 'Tympanoplasty only' group was defined as COM patients who underwent only tympanoplasty without mastoidectomy after an evaluation by otolaryngologist, and 'Mastoidecotmy' group was defined as COM patients who decided to undergo mastoidectomy regardless of whether tympanoplasty was performed or not. Among 106 of COM subjects, 38 were tympanoplasty only group and 68 were mastoidectomy group. The score of K-COMQ-12 showed significant differences among control, 'Tympanoplasty only' group and 'Mastoidectomy' group $(p<0.001)$. However, in the post-hoc test, the difference in the K-COMQ-12 score between the 'Tympanoplasty only' group and the 'Mastoidectoy group' was not statistically significant ( $p=0.700)$.

We tried to classify the COM subjects by the disease activity of COM according to the physical examination. 'Inactive COM' group was defined as having no evidence of active infection with dried up tympanic membrane (TM) whether the perforation is or not on physical examination. 'Active COM'

Table 4. Baseline characteristics of the study participants

\begin{tabular}{|c|c|c|c|}
\hline Characteristic & Control group $(n=106)$ & COM group $(n=106)$ & $p$-value \\
\hline Age (years) & $57.60 \pm 18.51$ & $57.18 \pm 13.60$ & 0.849 \\
\hline Sex, $m / f$ & $49(46.2) / 57(53.8)$ & $50(47.2) / 56(52.8)$ & $0.891^{\dagger}$ \\
\hline $\mathrm{BMI}\left(\mathrm{kg} / \mathrm{m}^{2}\right)$ & $23.90 \pm 2.80$ & $23.77 \pm 3.52$ & 0.768 \\
\hline HTN & $40(37.7)$ & $39(36.8)$ & $0.887^{\dagger}$ \\
\hline DM & $26(24.5)$ & $17(16.0)$ & $0.124^{\dagger}$ \\
\hline Lung disease & $11(10.4)$ & $9(8.5)$ & $0.638^{\dagger}$ \\
\hline Heart disease & $4(3.8)$ & $7(6.6)$ & $0.353^{\dagger}$ \\
\hline CVA & $0(0)$ & $1(0.9)$ & $0.316^{+}$ \\
\hline CKD & $13(12.3)$ & $9(8.5)$ & $0.368^{+}$ \\
\hline Liver disease & $3(2.8)$ & $1(0.9)$ & $0.313^{\dagger}$ \\
\hline Ear surgery & $0(0.0)$ & $37(34.9)$ & $<0.001^{*+}$ \\
\hline Noise exposure & $1(0.9)$ & $15(14.2)$ & $<0.001^{*+}$ \\
\hline Hearing Aid & $0(0.0)$ & $12(11.3)$ & $<0.001^{*+}$ \\
\hline
\end{tabular}

Values are expressed as mean $\pm S D$, or as numbers (percent). $* p<0.05$, tFisher's exact test. BMl: body mass index, HTN: hypertension, DM: diabetes mellitus, CVA: cerebrovascular accident, CKD: chronic kidney disease, SD: standard deviation

Table 5. Mean score of the K-COMQ-12 in the study and control groups

\begin{tabular}{|c|c|c|c|}
\hline & Control group $(n=106)$ & COM group $(n=106)$ & $p$-value \\
\hline K-COMQ-12 scores & $1.99 \pm 4.34$ & $22.69 \pm 12.41$ & $<0.001^{*}$ \\
\hline
\end{tabular}


Table 6. Mean score of K-COMQ-12 in control, inactive COM, and active COM groups

\begin{tabular}{lcccc}
\hline & Control $(n=106)$ & Inactive COM $(n=54)$ & Active COM $(n=52)$ & $p$-value \\
\hline K-COMQ-12 scores & $1.99 \pm 4.34$ & $17.83 \pm 9.73$ & $27.92 \pm 13.18$ & $<0.001^{*}$ \\
\hline
\end{tabular}

Values are expressed as mean \pm SD. The statistically significance was observed between all two groups in the post-hoc test. * $p$ <0.05. COM: chronic otitis media, K-COMQ-12: Korean version of Chronic Otitis Media Questionnaire-12, SD: standard deviation

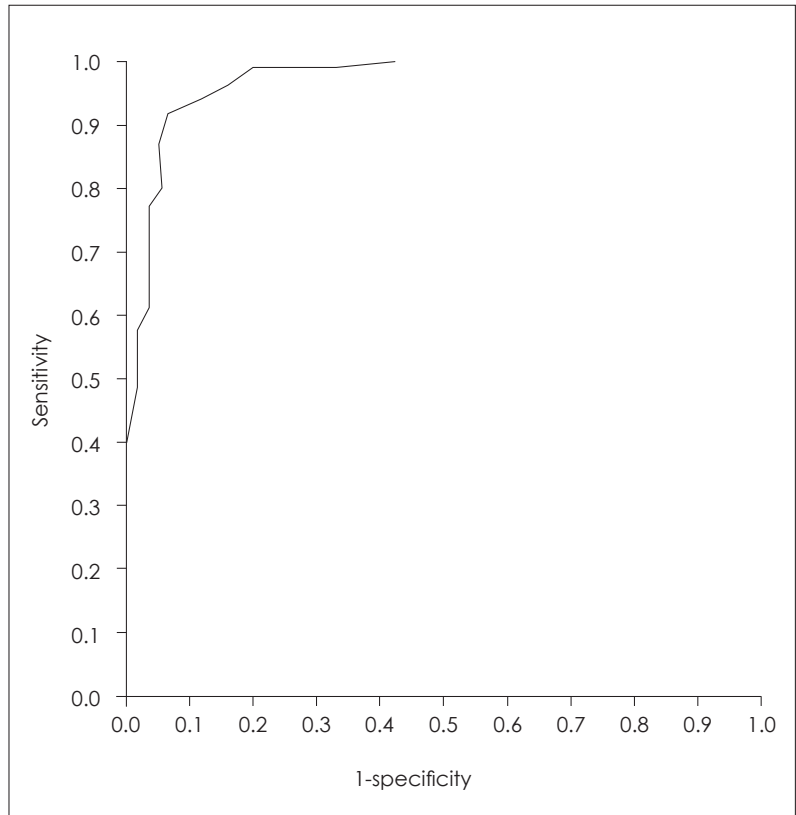

Fig. 2. ROC curve. The ability of K-COMQ-12 to detect normal and $\mathrm{COM}$ is expressed as area under the curve. In order to reflect the clinical significance of the K-COMQ-12 score, the critical point for distinguishing COM from normal was derived from the ROC curve with the point of 6. COM: chronic otitis media, K-COMQ-12: Korean version of Chronic Otitis Media Questionnaire-12, ROC: receiver operating characteristic.

group was defined as showing wet TM or retracted or adhered TM to middle ear space. We also compared the score of KCOMQ-12 among the control, 'Inctive COM', and 'Active COM' group. The difference of K-COMQ-12 score according to the disease activity of COM based on physical examination were statistically significant among all three groups $(p<0.001)$. The disease activity of COM goes higher, the K-COMQ-12 score went higher (Table 6).

\section{Cut-off value of COM using K-COMQ-I2}

To assess the meaningful cut-off value between COM patients and normal group, the ROC curve was used (Fig. 2). The value of area under the curve was 0.969 , which implies very high discriminatory power to distinguish subjects with the control and COM patients $(p<0.001)$. We could also identify which cut-off point that indicates best balance between sensitivity and specificity using ROC curve. A cut-off score of 6 of K-COMQ-12 sets 0.915 of sensitivity and 0.934 of speci- ficity. Therefore, using the K-COMQ-12 score of 6 of threshold, $91.5 \%$ of patients were correctly classified as COM, and $93.4 \%$ of non-patients were correctly categorized as normal.

\section{Discussion}

The patients-base measuring instruments of the HRQoL has become very important in healthcare. The COMQ-12 could provide information about symptoms they feel that are most important to the patients. ${ }^{8}$ It allows clinicians to quantify the severity of the symptoms that COM patients feel. Even if the severity of the disease is similar with the clinician's evaluation, it might be different in the inconvenience of each individual patient. Using COMQ-12, the clinician could identify the degree of discomfort caused by COM of the individual patient and determine how much the discomfort can be relieved during the treatment courses. ${ }^{8)}$ We translated COMQ-12 into Korean and tested it for validity, which allows patients with otitis media using Korean to use the tools to quantify the severity of their symptoms.

In our study, Cronbach's alpha of K-COMQ-12 was 0.939, suggesting good internal consistency. It is the highest value than any other version of COMQ-12. The original version of COMQ-12 reported 0.889 of Cronbach' alpha, Dutch, Russian, Portuguese, Serbian and Kannada version of COMQ-12 showed $0.833,0.860,0.85,0.84$, and 0.88 of Cronbach's alpha value. ${ }^{8,11,13-16)}$ The item-total correlation coefficients of KCOMQ-12 ranged from 0.548 to 0.822 . This indicates that all individual items correlated well with the total score.

Factor analysis was used to assess the internal structure of the K-COMQ-12, and two factors were identified according to eigenvalues and scree plot. However, there were no titles covering the items that make up each factor. Table 2 shows that items 5, 6, 9, 10, and 11 tend to be difficult to be classified as an specific factor. With the exception of these questions, the factor 1 can be defined as "symptoms associated with otorrhea" and the factor 2 as "discomfort associated with hearing ability and tinnitus (hearing symptoms)." However, this is not the preferred method. Besides, in original COMQ-12, eight questions (numbers 1-7 and 12) include severity of disease, whereas the remaining four questions (numbers 8-11) describe 
the frequency of disease occurrence, but they were not developed through factor analysis. ${ }^{8)}$

Our study shows that the K-COMQ-12 score in patents with a COM was significantly higher than that of the control group. The mean value and SD of K-COMQ-12 score showed 1.99 4.34 in control group and 22.69 \pm 12.41 in COM group. It was similar with the original version of the COMQ-12, and the follow-up study of normal patients. ${ }^{8,18)}$

After we divided COM group into subgroups according to the surgery the patient underwent which reflect the severity of COM, the K-COMQ-12 score goes higher as the severity of COM increased. However post-hoc test revealed there was no statistically significance between 'Tympanoplasty only' group and 'Mastoidectomy' group. As the authors of original version of COMQ-12 and the Russian, Portuguese, and Serbian versions were grouped by COM patients based on physical examination, compared the COMQ-12 scores, we also tried to divide COM patients following disease activity based on physical examination. ${ }^{8,13-15)}$ Considering that COMQ-12 is a questionnaire measuring inconvenience caused by COM, it is more appropriate to classify the patient based on the physical examination that reflects the disease activity. The score of K-COMQ-12 showed an increase as disease activity increased which is similar to the COMQ-12 validation study in other languages. $^{8,13-15)}$ Therefore, The K-COMQ-12 score could be used an objective measurement tool reflects not only the difference between control and COM group, but also the disease activity of COM.

Our study shows that a cut-off value of 6 was determined between COM group and normal group. However, it is difficult to interpret K-COMQ-12 as a diagnostic tool. COM could be diagnosed only by simple consultation without the great effort of the clinician. Many of clinical results, including physical examination, PTA, TBCT could help to evaluation of COM, but not just based on this questionnaire. K-COMQ-12 is a tool that only reflects the patient's HRQoL of COM. As reported by Phillips, et al., ${ }^{18)}$ patients who reported lower score than the cut-off value of 6 in K-COMQ-12, are seriously considered before contemplating intervention. ${ }^{15)}$

Unusually, COM patients answered that they were more exposed to the noise than the normal group. They were aware that their impaired hearing ability due to COM makes listen to loud sounds in daily life. We thought that it is the result of relatively high noise exposure in COM patients.

In conclusion, the K-COMQ-12 is a reliable and valid tool to assess HRQoL in patient with COM. It has high internal consistency and the K-COMQ-12 could be also used as an objective tool that reflects the disease activity of COM. The cutoff value of 6 in K-COMQ-12 should be interpreted that having just statistical meaningful value, because of diagnosis of COM should be conducted by clinician based on various clinical results.

\section{ORCID}

Sang Yoo Park https://orcid.org/0000-0001-8322-4701

Tae Hoon Kong https://orcid.org/0000-0002-5612-5705

\section{REFERENCES}

1) Nadol JB Jr, Staecker H, Gliklich RE. Outcomes assessment for chronic otitis media: the Chronic Ear Survey. Laryngoscope 2000; 110(3 Pt 3):32-5.

2) Park M, Lee JS, Lee JH, Oh SH, Park MK. Prevalence and risk factors of chronic otitis media: the Korean National Health and Nutrition Examination Survey 2010-2012. PLoS One 2015;10(5):e0125905.

3) Choi SY, Cho YS, Lee NJ, Lee J, Chung WH, Hong SH. Factors associated with quality of life after ear surgery in patients with chronic otitis media. Arch Otolaryngol Head Neck Surg 2012;138(9):840-5.

4) Yorgancılar E, Yildirim M, Gun R, Bakir S, Tekin R, Gocmez C, et al. Complications of chronic suppurative otitis media: a retrospective review. Eur Arch Otorhinolaryngol 2013;270(1):69-76.

5) Jung KH, Cho YS, Hong SH, Chung WH, Lee GJ, Hong SD. Qualityof-life assessment after primary and revision ear surgery using the chronic ear survey. Arch Otolaryngol Head Neck Surg 2010;136(4): 358-65.

6) Koller M, Lorenz W. Survival of the quality of life concept. Br J Surg 2003;90(10):1175-7.

7) Brouwer CN, Schilder AG, van Stel HF, Rovers MM, Veenhoven $\mathrm{RH}$, Grobbee DE, et al. Reliability and validity of functional health status and health-related quality of life questionnaires in children with recurrent acute otitis media. Qual Life Res 2007;16(8):1357-73.

8) Phillips JS, Haggard M, Yung M. A new health-related quality of life measure for active chronic otitis media (COMQ-12): development and initial validation. Otol Neurotol 2014;35(3):454-8.

9) Baumann I, Kurpiers B, Plinkert PK, Praetorius M. Development and validation of the Chronic Otitis Media Outcome Test 15 (COMOT-15). Measurement of health-related quality of life in patients with chronic otitis media. HNO 2009;57(9):889-95.

10) Vlastos IM, Kandiloros D, Manolopoulos L, Ferekidis E, Yiotakis I. Quality of life in children with chronic suppurative otitis media with or without cholesteatoma. Int J Pediatr Otorhinolaryngol 2009;73 (3):363-9.

11) Oorts E, Phillips J, Van de Heyning P, Yung M, Van Rompaey V. Dutch health-related quality of life measure for chronic otitis media. B-ENT 2015;11(4):291-5.

12) van Dinther J, Droessaert V, Camp S, Vanspauwen R, Maryn Y, Zarowski A, et al. Validity and Test-Retest Reliability of the Dutch Version of the Chronic Otitis Media Questionnaire 12 (COMQ-12). J Int Adv Otol 2015;11(3):248-52.

13) Kosyakov SI, Minavnina JV, Phillips JS, Yung MW. International recognition of the Chronic Otitis Media Questionnaire 12. J Laryngol Otol 2017;131(6):514-7.

14) Fonseca ACO, Ramos P, Balsalobre FA, Freitas EL, Phillips JS, Yung MW, Bento RF. Validation of a Portuguese version of the healthrelated quality of life measure for active chronic otitis media (COMQ12). Braz J Otorhinolaryngol 2018;84(6):708-12.

15) Bukurov B, Arsovic N, Grujicic SS, Haggard M, Spencer H, 
Marinkovic JE. Psychometric characteristics of the chronic Otitis media questionnaire 12 (COMQ - 12): stability of factor structure and replicability shown by the Serbian version. Health Qual Life Outcomes 2017;15(1):207.

16) Prabhu P, Chandrashekar A, Jose A, Ganeshan A, Kiruthika L. Development and Administration of Chronic Suppurative Otitis Media Questionnaire-12 (COMQ-12) and Chronic Otitis Media
Outcome Test-15 (COMOT-15) in Kannada. Int Arch Otorhinolaryngol 2018;22(2):102-12.

17) Hüttenbrink KB. Surgical treatment of chronic otitis media. I: indications, preoperative care and surgical principles. HNO 1994;42 (9):582-93.

18) Phillips JS, Yung MW. COMQ-12 scores in adult patients without chronic middle ear disease. Clin Otolaryngol 2014;39(6):362-7. 


\section{Appendix I}

\section{한국어판 만성 중이염 설문 12 (K-COMQ-12) \\ Korean version of COMQ-12 (K-COMQ-12)}

이 설문은 만성 중이염으로 인한 귀 증상이 환자에게 얼마나 불편함을 주는지 알아보고자 하는 설문입니다. 어떠한 장비 도 이를 대신할 수 없으며 오직 귀하만 알려주실 수 있습니다. 이 설문을 통하여 중이염으로 발생한 각 증상이 얼마나 중이 염 환자에게 불편함을 주는지 알 수 있습니다. 그리고 이것은 향후 중이염 환자들의 증상을 개선하는데 도움이 될 것입니다.

아래의 질문들에 대해서 충분히 생각하고 적절한 숫자를 골라보세요. 0 5까지의 숫자는 각 문항마다 각기 다른 의미를 가지고 있으며 각 문항에 안내되어 있습니다. 정답은 없습니다. 다섯 개의 숫자들 중에, 귀하에게 해당하는 숫자를 선택해주 시면 됩니다.

각각의 질문에 대해 과거 6개월동안 있었던 불편함에 대해 생각해보세요.

[예시] 다음 질문에 대하여 아래의 0 5까지 선택지 중 알맞은 것을 고르세요.

0: 전혀 아니다

1: 최소 3 달에 한 번

2: 최소 1달에 한 번

3: 최소 1 주에 한 번

4: 1주일에 여러 번

5: 매일

질문: 당신은 아침식사로 빵을 얼마나 자주 먹습니까?

$\begin{array}{llllll}0 & 1 & 2 & 3 & 4 & 5\end{array}$

※ 만약 어떤 사람이 $0,1,2,3,4,5$ 중 4를 고른다면 그 사람은 아침식사로 빵을 1 주일에 여러 번 먹지만 매일 먹지는 않는다는 뜻입니다.

질문에 대답할 때 어려움이 있다면 언제든 문의하여 주십시오. 감사합니다.

다음 질문에 대하여 각각의 증상들이 당신에게 얼마나 심한 영향을 주는지 아래의 선택지를 참고하여 해당하는 숫자에 표시해주세요.

0. 전혀 불편함이 없다.

1. 약간 불편하다.

2. 중간 정도 불편하다.

3. 매우 불편하지만, 참을 수 있다.

4. 매우 불편하고, 참기 어렵다.

5. 내가 겪은 불편함 중 가장 심하다. 


\section{증상의 심각도}

1. 귀에서 나오는 물이나 고름

$\begin{array}{llllll}0 & 1 & 2 & 3 & 4 & 5\end{array}$

2. 귀에서 나는 냄새

$\begin{array}{llllll}0 & 1 & 2 & 3 & 4 & 5\end{array}$

3. 집에 있을 때 잘 안들림(예: TV나 라디오의 소리를 더 높여야 한다.)

$\begin{array}{llllll}0 & 1 & 2 & 3 & 4 & 5\end{array}$

4. 여러 사람들과 대화할 때 잘 안들림 혹은 주위가 시끄러우면 소리가 잘 안 들림

$\begin{array}{llllll}0 & 1 & 2 & 3 & 4 & 5\end{array}$

5. 귀 안쪽이나 귀 주위의 불편한 느낌

$\begin{array}{llllll}0 & 1 & 2 & 3 & 4 & 5\end{array}$

6. 어지러운 느낌이나, 균형을 잃은 듯한 느낌

$\begin{array}{llllll}0 & 1 & 2 & 3 & 4 & 5\end{array}$

7. 이명이나 귀에서 나는 이상한 소리

다음 질문에 대하여, 각각의 증상들이 당신에게 얼마나 자주 영향을 주는지 아래의 선택지를 참고하여 해당하는 숫자에 표시해주세요.

0.6 개월 내에 1 번도 없음

1. 6 개월에 최소 1 번 이상

2. 3 개월에 최소 1 번 이상

3. 1 달에 1 번 이상

4. 1 주일에 1 번 이상

5. 거의 매일

\section{생활방식과 일에 대한 영향}

8. 집, 직장에서 일상 생활을 하기 힘든 날이 얼마나 자주 있나요?

$\begin{array}{llllll}0 & 1 & 2 & 3 & 4 & 5\end{array}$

9. 귀의 문제 때문에 샤워, 세수, 목욕을 원하는대로 못할때가 있나요?

(예: 샤워, 세수, 목욕 등이 귀 염증을 더 심하게 할까봐 씻지 못함)

\section{건강 서비스에 대한 영향}

10. 당신은 귀 문제로 얼마나 자주 의사를 만나나요?

11. 당신의 귀 문제로 얼마나 자주 약을 먹나요?(귀에 넣는 약 포함)

다음 질문에 대하여 각각의 증상이 당신에게 얼마나 나쁜 영향을 주는지 0 5 척도를 이용해 표시해 주세요. 0은 전혀 그 렇지 않다는 것을 의미하고, 5 는 아주 심하다는 뜻입니다.

\section{일반적 질문}

12. 당신은 귀 문제 때문에 얼마나 우울합니까?

모든 질문에 대답했는지 확인해 주시고 대답하기 어려운 질문은 문의하여 주십시오. 설문에 참여해 주셔서 대단히 감사합니다. 